\title{
Development of Solar Energy Dryer for Fish and Meat Tested in Modibbo Adama University of Technology Yola
}

\author{
D. Y. Dasin1, A. I. Zakari², I. Yahuza3 \\ ${ }^{1}$ Associate Professor, ${ }^{2}$ Graduate, ${ }^{3}$ Senior Lecturer \\ 1,2Department Of Mechanical Engineering, Modibbo Adama University Of Technology, Yola, Nigeria \\ 3Department of Automotive Engineering, Abubakar Tafawa Balewa University, Bauchi, Nigeria
}

\begin{abstract}
A domestic solar dryer for drying meat and fish has been designed, constructed and tested in Modibbo Adama University of Technology, Yola - Nigeria. The dryer is a passive indirect mode type using natural convection with the collector unit attached to the dryer. It is made up of plywood, glass, mild steel sheet, wire net and paint. The collector dimension was $70 \mathrm{~cm} x 60 \mathrm{~cm} x$ $30 \mathrm{~cm}$. The drying chamber was $60 \mathrm{~cm} \times 60 \mathrm{~cm} \times 70 \mathrm{~cm}$; it has two trays for drying purposes at $20 \mathrm{~cm}$ spacing, which can hold $2 \mathrm{~kg}$ of fish and meat each. Fish and meat (0.5 kilogram of each) were dried in the dryer. The temperatures of the different components of the dryer increases with time and reaches maximum value of 370C for average ambient temperature, 350C for the product temperature, $400 \mathrm{C}$ for the average collector temperature and $420 \mathrm{C}$ for the average drying chamber temperature at 2:00 PM local time. The weight of the samples reduced were $0.029 \mathrm{~kg}$ and $0.019 \mathrm{~kg}$ at an average drying rate of $0.032 \mathrm{~kg} / \mathrm{hr}$ and $0.040 \mathrm{~kg} / \mathrm{hr}$ for meat and fish respectively, at an average solar radiation of $521 \mathrm{~W} / \mathrm{m} 2$ and average relative humidity of $26.4 \%$. The drying efficiency was obtained to be $27 \%$.
\end{abstract}

Keywords: Solar Dryer, Moisture Content, Meat, Fish, Yola, Solar Radiation

\section{INTRODUCTION}

The drying for food preservation is very general for a number of agriculture and food products. Drying is a better option than refrigeration of food products with respect to the cost and complexity of devices. As energy is a crucial issue in case of food preservation methods, a dryer uses non - conventional energy like solar energy to ensure minimum investment and reliability.

Open-air sun drying has been used since time immemorial to dry plants, seeds, fruits, meat, fish, wood and other agricultural or forest products as a means of preservation. However, this has some limitations among which are; high labour costs, large area requirement, lack of ability to control the drying process, possible degradation due to biochemical and micro-biological reactions, insect infestation and so on [1].

Solar food dryer is a device that can be used to dry food effectively and efficiently with lesser time compared to openair sun drying. In order to benefit from the free and environmentally friendly energy source provided by the sun, several attempts have been made in recent years to develop solar drying mainly for preserving agricultural and forest products [2]. Solar food dryer is built to dry food using solar energy. Sunlight enters an enclosed chamber (sun collector) where it strikes a dark surface converting its energy to heat. The heat dries the food. Airflow is accomplished by a natural draft (warm air rises) which can be controlled by adjusting vents. The same principle is used for controlling draft in a traditional smokehouse.

Dry fish production mainly consists of micro level cottage enterprises, carried out predominantly by fisherwomen as a supplementary source of income. As such, the quantities produced tend to be low. Furthermore due to the long drawn drying process, the moisture retained creates an ideal environment for growth of fungi. The practice of drying the fish in the open under the sun affects the hygienic conditions of the dried fish, due to the high risk of contamination with dust particles and harmful contaminants.

Fish is known to be a source of protein rich in essential amino acids (lysine, methionine, cystine, threonine, and tryptophan) [3], micro- and macroelements (calcium, phosphorus, fluorine, iodine), fats that are valuable sources of energy, fat-soluble vitamins, and unsaturated fatty acids that, amongst other benefits, have a hypocholesterolemic effect (antiarteriosclerosis) [4]. Fish and its residue are an easily digestible source of high biological value protein, essential fatty acids, and minerals as well as vitamins A, D, and B complex, all of which make for a product of high nutritional value [5].

Fish is currently being used as a good tool for food therapy and source of therapeutic substances for the treatment of coronary diseases, auto-immune diseases, anemia and protein energy malnutrition [6]. However, fish is highly perishable because it provides favorable medium for the growth of microorganisms after death [7, 8 and 9].

The manufacture of fermented meat products, such as raw hams or dry sausages is an example, where drying is one processing component amongst several others. To have an extended shelf life, fermented products need to lose moisture during their fermentation, they are dehydrated or "dried" to a certain extend. Drying and fermentation must go hand in hand to achieve the desired flavour and shelf life. The drying of such products is mostly done in climatized chambers with exact temperature and humidity parameters. Drying under natural conditions is increasingly rare. Another example is the drying of meat preparations in ovens with temperatures in the range of $70-80^{\circ} \mathrm{C}$, to become fast-dried products such as beef sticks formed of ground, salted and flavoured meat. Furthermore, for a number of indigenous 
meat products, moderate drying is part of the manufacturing technique with the aim of lowering the water activity $\left(a_{w}\right)$, thus curbing microbial growth [10].

To arrest these problems, many designs of solar dryers have been developed for the preservation of fish and meat. Solar dryers employ some means of collecting or concentrating solar radiation with the result that elevated temperatures and, in turn, lower relative humidity is achieved for drying [11]. Along with the evaluation of the effectiveness, efficiency, and performance of the low-cost solar driers in terms of moisture reduction, it is also desirable to analyze the organoleptic characteristics of the final dried products coming from the low-cost solar driers. This is usually done by means of human senses or organs to test for some properties on the dry product. [11] Used appearance, flavor, texture, filthiness, scales, wetness, and saltiness as organoleptic characteristics of dried fish products. Several studies have been done on the organoleptic characteristics of various fish/meat species dried by different methods.

\section{DESIGN CONSIDERATION AND ANALYSIS}

The following points were considered for the design of the solar dryer system:

A. Angle of tilt of the solar collector

B. The amount of moisture to be removed from a given quantity of food.

C. Daily solar radiation to determine the energy received by the dryer per day.

D. Daily sunshine hours for the selection of the total drying time.

\section{Angle of tilt $(\boldsymbol{\beta})$ of the solar collector}

The angle of tilt $(\beta)$ of the solar collector as reported by [12] is given by:

$$
\beta=10^{0}+\text { lat } \phi
$$

Where, lat $\phi$ is the latitude of the collector location which is $9.14^{0} \mathrm{~N}$.

\section{Moisture content (M. C.)}

The moisture content (\%) as reported by [13] is given by:

$$
\text { M. } C .=\frac{\left(M_{i}-M_{\digamma}\right)}{M_{i}} \times 100
$$

Where,

$$
\begin{aligned}
& M_{i}=\text { mass of sample before drying }(\mathrm{kg}) \\
& M_{f}=\text { mass of sample after drying }(\mathrm{kg}) .
\end{aligned}
$$

\section{Average Drying Rate for Drying the Products}

The average drying rate in $\mathrm{Kg} / \mathrm{hr}$ for drying the products was given by [1]:

$$
d_{A}=\frac{M_{W}}{t_{d}}
$$

Where:

$M_{W}=$ mass of moisture content removed from the food,

$t_{d}=$ drying time (hrs)

Mass of Air Needed for Drying

The mass of air needed for drying was given by [1]:

$$
M_{a}=\frac{d_{A}}{W_{f}-W_{i}}
$$

Where:

$d_{A}=$ Average drying rate

$W_{i}=$ Initial humidity ratio, $\mathrm{kg} \mathrm{H} 2 \mathrm{O} / \mathrm{kg}$ dry air

$w_{f}=$ Final humidity ratio, kg H20/kg dry air.

Final or Equilibrium Relative Humidity

The final relative humidity or equilibrium relative humidity was calculated using sorption isotherms as follows:

$a_{w}=1-\exp \left[-\exp \left(0.194+0.5639 \mathrm{hM}_{d}\right)\right]$

$$
\begin{aligned}
& M_{a^{n}}=\frac{M_{f}}{\left(100-M_{f}\right)} \\
& E R H=100 a_{w}
\end{aligned}
$$

Where:

$\mathrm{ERH}=$ Equilibrium relative humidity

$a_{w}=$ Water activity,

$M_{f} \quad=$ Final moisture content \% wet basis

$M_{a}=$ Moisture content dry basis, (Kg water $/$ Kg solids)

\section{Required Pressure}

The pressure difference across the food bed will be solely due to density difference between the hot air inside the dryer and the ambient air. Air pressure can be determined by equation given by (Dasin et al., 2015):

$$
P=0.00308 g\left(T_{C}-T_{a}\right) H
$$

$\mathrm{H}$ is the pressure head (height of the hot air column from the base of the dryer to the point of air discharge from the dryer) in meters; $\mathrm{P}$ is the air pressure in Pascal and $\mathrm{g}$ is the acceleration due to gravity, $9.81 \mathrm{~m} / \mathrm{s}^{2} ; T_{a}$ is the ambient temperature in ${ }^{\circ} \mathrm{C}$.

\section{The Energy Balance of the Absorber}

The energy balance on the absorber is obtained by equating the total heat gained to the total heat lost by the absorber of the solar collector.

Therefore,

$$
I A_{c}=Q_{u}+Q_{\text {cond }}+Q_{\text {conv }}+Q_{R}+Q_{p}
$$

Where:

$I \quad=$ rate of total radiation incident on the absorber's surface $\left(\mathrm{Wm}^{-2}\right)$;

$A c=$ collector area $\left(\mathrm{m}^{2}\right) ;$

$Q_{u} \quad=$ rate of useful energy collected by the air (W);

$Q_{\text {cond }}=$ rate of conduction losses from the absorber $(\mathrm{W})$;

$Q_{\text {conv }}=$ rate of convective losses from the absorber $(\mathrm{W})$;

$Q_{R} \quad=$ rate of long wave re-radiation from the absorber (W);

$Q_{\rho} \quad=$ rate of reflection losses from the absorber $(\mathrm{W})$.

The three heat loss terms $Q_{\text {cond }}, Q_{\text {conv }}$ and $Q_{\mathrm{R}}$ are usually combined into one-term $\left(Q_{\mathrm{L}}\right)$,

$$
Q_{L}=Q_{\text {eond }}+Q_{\text {conv }}+Q_{\mathrm{K}}
$$

If $\tau$ is the transmittance of the top glazing and it is the total solar radiation incident on the top surface, therefore,

$$
I A_{e}=\tau I T A_{\sigma}
$$

The reflected energy from the absorber is given by the expression:

$$
Q_{p}=\rho \tau I T A_{e}
$$


$Q_{L}$ composed of different convection and radiation parts. It is presented in the following form

$$
Q_{L}=U_{L} A_{s}\left(T_{s}-T_{s}\right)
$$

Where:

$U_{\Sigma}=$ overall heat transfer coefficient of the absorber $\left(\mathrm{Wm}^{-2} \mathrm{~K}^{-1}\right)$;

$T_{c} \quad=$ temperature of the collector's absorber $(\mathrm{K})$

$\mathrm{T}_{\mathrm{a}} \quad$ = temperature of the ambient air $(\mathrm{k})$

The useful energy gained by the collector is therefore expressed as:

$$
Q_{V}=(a b)_{T}-U_{L}\left(T_{C}-T_{a}\right)
$$

And the energy per unit area $\left(q_{u}\right)$ of the collector is given as:

$$
q_{u}=(\alpha \tau) I_{T}-U_{L}\left(T_{C}-T_{a}\right)
$$

\section{Thermal Efficiency of the Collector}

The thermal efficiency of the collector as defined by [1] is given as:

$$
\eta_{C}=\frac{Q_{V}}{A_{C} I_{T}}
$$

Where:

$$
\begin{aligned}
& Q_{U}=\text { useful energy gained } \\
& A_{C}=\text { collector area and } \\
& I_{T} \quad=\text { total solar radiation incident on the top surface. }
\end{aligned}
$$

\section{Dryer Efficiency}

The dryer efficiency was computed by [1] as:

$$
\eta_{d}=\frac{M L}{l_{c} A_{c} t_{a d}}
$$

Where:

$\mathrm{M}=$ mass of the food $(\mathrm{Kg})$

$\mathrm{L}=$ latent heat of vaporization $\mathrm{kJ} / \mathrm{kg}$ of $\mathrm{H}_{2} \mathrm{O}$.

$t_{d}=$ drying time (s).

The latent heat of vaporization is given by [14] as:

$$
i=4.186 \times 10^{2}\left\{597-0.56\left(T_{p}\right)\right\}
$$

Where:

$T_{p}=$ product temperature $(\mathrm{k})$

\section{MATERIALS USED FOR THE CONSTRUCTION}

\section{Wood:}

wood, metal and plastic were considered as materials for the construction of the solar dryer, but of all, wood was seen to be the cheapest and readily available, hence selected as suitable based on its low cost. In terms of the properties wood is seen as a very good insulator which will help in minimizing heat loss from the system, these properties make it to be preferred to metal which is a conductor of heat and will aid heat loss from the system. Wood does not impose any heath issue when used and therefore is the most suitable material that can be used for the casing of the dryer.

\section{Glass:}

Glass is used as the glazing for the collector and is seen to be the most suitable material that can be used because it transmits all the light reelected on it. It transmits solar radiation incident on it into the system and resist the flow of heat energy out of the system. It is readily available and does not pose a threat in terms of health issue.
Therefore, it is considered to be the most suitable material for the collector's cover.

\section{Aluminium metal:}

Aluminium metal and mild steel can be used as the absorber plate for the collector but aluminium is selected because it is cheaper compared to mild steel. Also in terms of its properties, it absorbs heat at a high rate when painted black and is not hazardous to the human health. Therefore, it is the most suitable material that can be used for the absorber plate of the collector.

\section{Wooden frame:}

This was used as the frame for the trays because it will minimize heat loss from system.

\section{Nails and Glues:}

These were used as fasteners and adhesives for the construction of the solar dryer. These materials were selected because they are the best materials to use as fasteners and adhesives; also, they are readily available in the market and pose no health hazard to the person using them.

\section{Net:}

This was used as the dryer tray screen; it is selected because it has holes that will aid the flow of air. It is readily available in the market and does not pose any threat to the health of the person using them.

\section{Hinges:}

This was used for the door of the drying chamber to aid easy opening and closing of the door.

\section{Black paint:}

This was used to coat the absorbers surface. This colour of paint was selected because a black paint when painted on materials has the ability to absorb solar radiation, therefore for effective and efficient absorption of solar radiation the absorber was painted with a black paint.

\section{TESTING OF THE SOLAR DRYER}

The testing of the solar dryer was done in the months of January and February. The dryer was placed under the sun with the collector facing south for optimum performance. A K-type thermocouples and Kane-May (KM 330) digital temperature output instrument were used to measure the ambient temperature, chamber temperature and the items to be dried. Their size was such that caused less obstruction to heat and their accuracy was $\pm 0.1{ }^{\circ} \mathrm{C}$, when employed in conjunction with the digital temperature output meter Kane - May (KM330). Instantaneous global components of solar radiation were measured using pyranometer (CM6B model, KIPP \& ZONEN DELFT Holland) and CM11/121 fitted with shadow ring measuring the instantaneous diffuse component of solar radiation. Both were calibrated as $9.63 \times$ 10-6 V/WM-2. Wind speed was measured using cup counter Anemometer and relative humidity meter PCE - HT 71N and it is mainly used as a data logger with Measurement range: $\mathbf{0}$ ... 100\% RH, Accuracy: $\pm 3 \%$ RH (20 ... 80\%).

The drying chamber was loaded with fish and meat estimated to weigh averagely $500 \mathrm{~g}$ each. Under no load condition, the temperature of the heated air inside the dryer, the collector chamber and the ambient air was taken every one-hour interval, starting from $9 \mathrm{AM}$ to $5 \mathrm{PM}$. The testing results are presented in tables 1 and 2 . 
International Journal of Trend in Scientific Research and Development (IJTSRD) @ www.ijtsrd.com eISSN: 2456-6470

Table 1: Hourly variation of temperature and moisture content in the solar dryer for $03 / 02 / 2018$

\begin{tabular}{|c|c|c|c|c|c|c|c|c|}
\hline \multirow{2}{*}{$\begin{array}{c}\text { Time } \\
\text { (hours) }\end{array}$} & \multirow{2}{*}{$\begin{array}{l}\text { Ambient } \\
\text { Temp. } \\
\left.\text { ( }{ }^{\circ} \mathrm{C}\right)\end{array}$} & \multirow{2}{*}{$\begin{array}{l}\text { Chamber } \\
\text { Temp. } \\
\left({ }^{\circ} \mathrm{C}\right)\end{array}$} & \multirow{2}{*}{$\begin{array}{l}\text { Collector } \\
\text { Temp. } \\
\left({ }^{\circ} \mathrm{C}\right)\end{array}$} & \multicolumn{2}{|c|}{ Moisture Content } & \multirow{2}{*}{$\begin{array}{l}\text { Wind } \\
\text { Speed } \\
(\mathrm{m} / \mathrm{s})\end{array}$} & \multirow{2}{*}{$\begin{array}{c}\text { Global } \\
\text { Radiation } \\
\left(\mathrm{W} / \mathrm{m}^{2}\right)\end{array}$} & \multirow{2}{*}{$\begin{array}{c}\text { Relative } \\
\text { Humidity } \\
(\%)\end{array}$} \\
\hline & & & & Meat (kg) & Fish (kg) & & & \\
\hline 9:00 & 27 & 25 & 36 & 0.5 & 0.5 & 1.135 & 569.65 & 38.60 \\
\hline $10: 00$ & 29 & 34 & 33 & 0.44 & 0.42 & 1.154 & 625.46 & 33.43 \\
\hline 11:00 & 31 & 38 & 37 & 0.40 & 0.33 & 0.82 & 639.05 & 26.81 \\
\hline $12: 00$ & 33 & 36 & 34 & 0.37 & 0.26 & 0.931 & 650.87 & 19.36 \\
\hline $13: 00$ & 35 & 38 & 36 & 0.36 & 0.24 & 1.708 & 324.38 & 18.25 \\
\hline $14: 00$ & 36 & 37 & 37 & 0.34 & 0.23 & 0.743 & 474.70 & 16.79 \\
\hline $15: 00$ & 33 & 34 & 36 & 0.32 & 0.23 & 1.059 & 382.44 & 15.31 \\
\hline $16: 00$ & 33 & 37 & 36 & 0.31 & 0.22 & 1.235 & 143.58 & 14.94 \\
\hline $17: 00$ & 33 & 33 & 34 & 0.31 & 0.21 & 0.852 & 35.92 & 14.21 \\
\hline
\end{tabular}

Table 2: Hourly variation of temperature and moisture content in the solar dryer dryer for 04/02/2018

\begin{tabular}{|c|c|c|c|c|c|c|c|c|}
\hline \multirow[b]{2}{*}{$\begin{array}{c}\text { Time } \\
\text { (hours) }\end{array}$} & \multirow{2}{*}{$\begin{array}{l}\text { Ambient } \\
\text { Temp. } \\
\left({ }^{\circ} \mathrm{C}\right) \\
\end{array}$} & \multirow{2}{*}{$\begin{array}{c}\text { Chamber } \\
\text { Temp. } \\
\left({ }^{\circ} \mathrm{C}\right) \\
\end{array}$} & \multirow{2}{*}{$\begin{array}{l}\text { Collector } \\
\text { Temp. } \\
\left({ }^{\circ} \mathrm{C}\right) \\
\end{array}$} & \multicolumn{2}{|c|}{ Moisture Content } & \multirow{2}{*}{$\begin{array}{l}\text { Wind } \\
\text { Speed } \\
(\mathrm{m} / \mathrm{s}) \\
\end{array}$} & \multirow{2}{*}{$\begin{array}{c}\text { Global } \\
\text { Radiation } \\
\left(\mathrm{W} / \mathrm{m}^{2}\right)\end{array}$} & \multirow{2}{*}{$\begin{array}{c}\text { Relative } \\
\text { Humidity } \\
(\%) \\
\end{array}$} \\
\hline & & & & Meat (kg) & Fish (kg) & & & \\
\hline $10: 00$ & 32 & 41 & 38 & 0.5 & 0.5 & 2.315 & 744.9 & 38.31 \\
\hline $11: 00$ & 33 & 37 & 36 & 0.40 & 0.39 & 1.729 & 549.3 & 26.72 \\
\hline $12: 00$ & 35 & 42 & 40 & 0.37 & 0.33 & 1.968 & 655.3 & 33.32 \\
\hline $13: 00$ & 35 & 45 & 41 & 0.32 & 0.28 & 1.414 & 531.2 & 24.36 \\
\hline $14: 00$ & 38 & 46 & 43 & 0.28 & 0.24 & 1.439 & 377.3 & 21.54 \\
\hline $15: 00$ & 36 & 39 & 37 & 0.25 & 0.23 & 0.987 & 155.7 & 20.43 \\
\hline $16: 00$ & 33 & 35 & 35 & 0.24 & 0.20 & 0.856 & 26.14 & 23.22 \\
\hline $17: 00$ & 32 & 33 & 32 & 0.22 & 0.19 & 0.643 & 10.16 & 18.34 \\
\hline
\end{tabular}

\section{RESULTS AND DISCUSSION}

A temperature reading of the various components of the dryer was recorded on hourly basis starting from 9:00 AM 5:00 PM. Performance characterization of the solar dryer was done using slices of meat and fish. This will enable quick drying and easy circulation of air within the drying chamber.

The results obtained shows that the performance of the solar energy dryer is dependent on the intensity of the solar radiation incident on the collector and the ambient temperature. All drying conditions of the solar drying process were monitored and presented in tables 1 and 2.

Figures 1 and 2 were obtained for drying of fish and meat on $03 / 02 / 2018$ and $04 / 02 / 2018$ at average relative humidity of $26.4 \%$ and average global solar radiation of $521.3 \mathrm{~W} / \mathrm{m}^{2}$. The results indicates that average percentage moisture content present in the meat and fish were $47 \%$ w.b. and $60 \%$ w.b. respectively.

Figures 3 and 4 depict the moisture loss by weight for the products over the period of drying. The average mass of moisture content removed from meat and fish are $0.24 \mathrm{~kg}$ and $0.3 \mathrm{~kg}$ at an average drying rate of $0.032 \mathrm{~kg} / \mathrm{hr}$ and 0.040 $\mathrm{kg} / \mathrm{hr}$ respectively as shown in figures 3 and 4 . The efficiency of the dryer for drying of the fish and meat was determined to be $27 \%$. The figures shows that at 9:00 A.M. when the average ambient temperature was $30^{\circ} \mathrm{C}$, the product temperature was $31^{\circ} \mathrm{C}$, the average collector temperature was $37^{\circ} \mathrm{C}$ and the average drying chamber temperature was $38^{\circ} \mathrm{C}$ for the two tests conducted. The temperatures increases with time and reaches maximum value of $37^{\circ} \mathrm{C}$ for average ambient temperature, $35^{\circ} \mathrm{C}$ for the product, $40^{\circ} \mathrm{C}$ for the average collector and $42^{\circ} \mathrm{C}$ for the average drying chamber at 2:00 PM. It then decreases with time at round 4:00 P.M. with the ambient temperature at $33^{\circ} \mathrm{C}$, the product temperature at $39^{\circ} \mathrm{C}$, the collector temperature at $36^{\circ} \mathrm{C}$ and the drying chamber temperature at $36^{\circ} \mathrm{C}$. This then shows that minimum value of temperatures for the product, collector and the drying chamber were obtained in the morning, while their maximum values were obtained at midday when insolation is high.

\section{CONCLUSION}

A solar dryer for fish and meat was successfully designed and constructed with locally available materials. The maximum temperature obtained in the collector was $43^{\circ} \mathrm{C}$, while that of the drying chamber was $46^{\circ} \mathrm{C}$. Fish was observed to have dried at faster rate compared to meat using its reduction in weight as a basis for comparison. The fish and meat were not exposed to direct sunlight and risk of animal/ insect contamination was eliminated. The efficiency of the dryer was $55 \%$ when compared to similar dryers is within the range of 50\% (Ajibde, 2010 and (Dahiru, 2013).
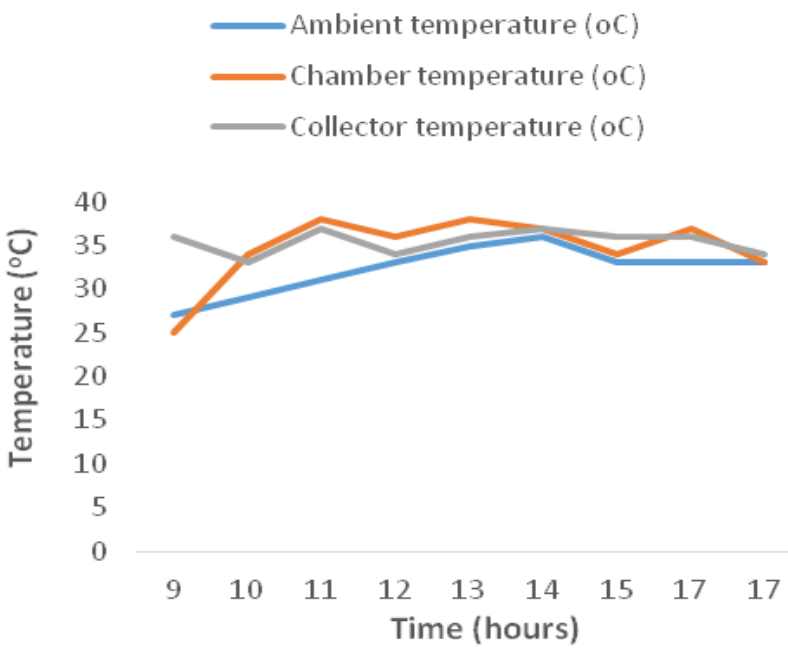

Figure 1: Graph of variation of temperature variation with time for $03 / 02 / 2018$ 
- Ambient temperature $(\mathrm{oC})$

Chamber temperature $(\mathrm{oC})$

Collector temperature $(\mathrm{oC})$

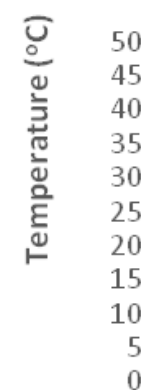
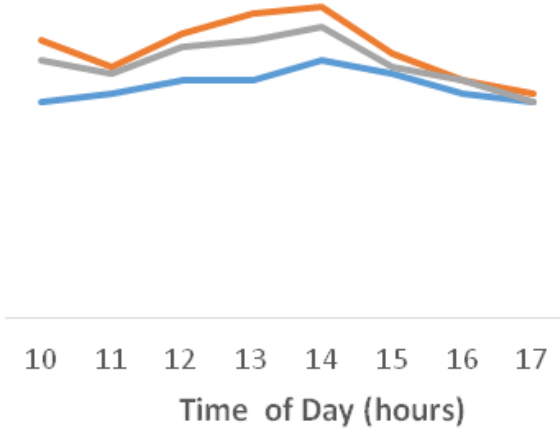

Figure 2: Graph of variation of temperature variation with time dryer for $04 / 02 / 2018$

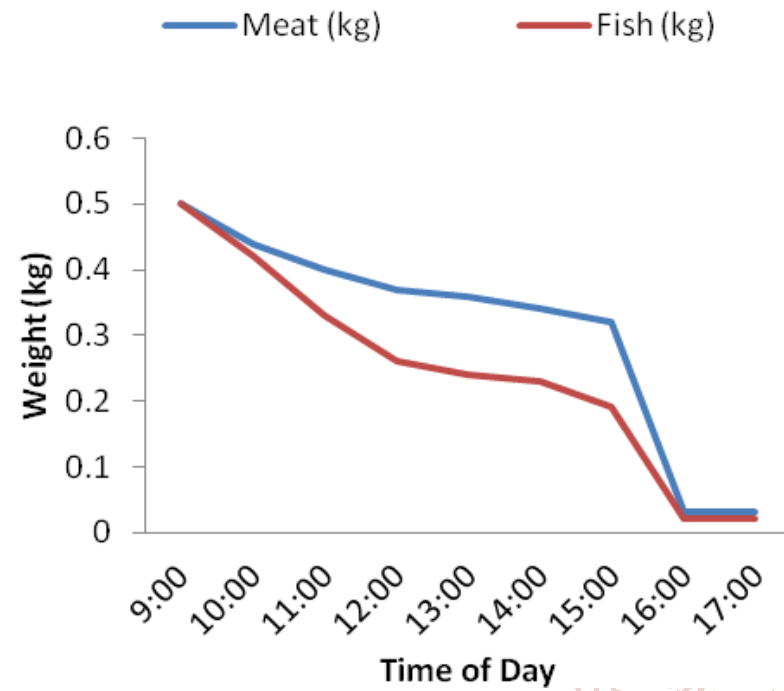

Figure 3: Graph of reduction of weight versus time for meat and fish
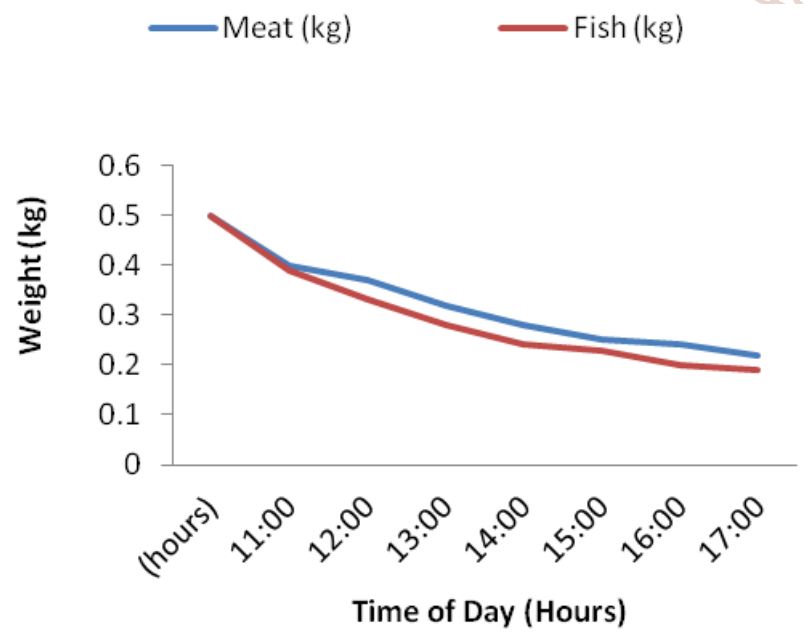

Figure 4: Graph of reduction weight versus time for meat and fish

\section{REFERENCES}

[1] D. Y. Dasin, N. Y. Godi and O. C. Kingsley (2015). Experimental Investigations of the Performance of Passive Solar Food Dryer Tested in Yola - Nigeria. International Journal of Energy Engineering, Vol. 5(1): Pp. 9-15.

[2] Taylor and Francis (2006): Handbook of industrial drying. E-book accessed on the 30th of May 2013.

[3] Umogbai V. I. and Iorter H. A.(2013). Design, Construction and performance evaluation of a passive solar dryer for maize cobs, African Journal of food Science and technology

(ISSN: 2141 5455) Vol. 4 (5) Pp. 110 - 115.

[4] Ismail H. M. (2005). The role of omega-3 fatty acids in cardiac protection: an overview. Front. Biosci. 10:1079-1088.

[5] Kristinsson H.G. and Rasco B. A. (2000). Fish protein hydrolysates: production, biochemical and functiona properties. Food. Sci. Nutr. 40:43-81.

[6] Glomset J. (1986). Nutrition research. New England. J. Med. 312:1253- 1254

[7] Ojutiku R. O., Kolo R. J. and Mhammed M. L. (2009). Comparative study of sun drying and solar tent drying of Hyperopisus bebeoccidentalis. Pak. J. Nutr. 8(7):955957.

[8] Aliya G., Humaid K., Nasser A., Sami G., Aziz K., Nashwa M. and Ponnerassery S. S. (2012). Effect of the freshness of starting material on the final product quality of dried salted shark. Adv. J. Food. Sci. Technol. $4(2): 60-63$.

[9] Oparaku N. F. and Mgbenka B. O. (2012). Effects of electric oven and solar dryer on a proximate and water activity of Clarias gariepinus fish. Eur. J. Sci. Res. 81:139-144

[10] Sikorski Z. E. (1994). Charakterystyka białek głównych surowców_zywnos'ciowych. In: Chemiczne i funkcjonalne włas'ciwos'ci składników zywnos'ci.WN-T, Warszawa.

[11] Haftom Z., Tsegay T. and Tesfay M. (2017). Evaluation of solar dryers on drying and sensory properties of salted Tilapia filets, Tigray, Northern Ethiopia. ISABB Journal of Food and Agriculture Science, Vol. 7(2), Pp. 10-18.

[12] Alamu, O. J., Nwaokocha, C. N., \& Adunola, O. (2010). Design and Construction of a Solar Food Dryer, (16), 71-82.

[13] Ezekoye, B. A and Enebe, O.M. (2006). Development and performance evaluation of modified integrated passive solar grain dryer. The Pacific Journal of Science and Technology, (2): Pp.185-190.

[14] Youcef-Ali S., Messaoudi H., desmons J. Y., Abene A., and Le Ray M. (2001): Determination of the average coefficient of internal moisture transfer during the drying of a thin bed of potato slices. Journal of food engineering. Vol. 48(2): pp. 95-101. 